Цвірко О. О., д.е.н., професор

Причорноморський науково-дослідний інститут

економіки та інновачій

м. Одеса, Україна

DOI: https://doi.org/10.30525/978-9934-26-145-9-20

\title{
ЕКОНОМІКА УКРАЇНИ В КОНТЕКСТІ ТРУДОВОЇ МІГРАЦІЇ НАСЕЛЕННЯ
}

Міграція сьогодні стала глобальним явищем зростаючого масштабу i складності. Багато країн світу тепер $€$ місцем походження, транзиту або призначення працівників-мігрантів. Динаміка трудової міграції може значно впливати на соціальноекономічну ситуацію в країнах походження, транзиту або призначення мігрантів. В останніх трудова міграція може сприяти омолодженню робочої сили, забезпечити функціонування трудоінтенсивних галузей, таких як сільське господарство, будівництво і особисті послуги, стимулювати підприємництво, підтримати роботу систем соціального захисту, а також допомогти в задоволенні кадрових потреб. У свою чергу, країни походження отримують користь у вигляді грошових переказів, які мігранти відправляють на батьківщину своїм сім'ям, i y вигляді інвестицій, технологій i найважливіших навичок, джерелом яких виступають повернулися мігранти та спільноти співвітчизників за кордоном (діаспори)

За даними ООН, у 2020 році кількість міжнародних мігрантів досягла 281 мільйон чоловік, що складає близько $3,5 \%$ всього населення планети. Число людей, що живуть за межами країни свого народження або громадянства, досягло 281 мільйона в 2020 році, в порівнянні 3173 мільйонами в 2000 році i 221 мільйоном в 2010 році. Оскільки кількість міжнародних мігрантів зростала швидше ніж населення світу, частка міжнародних мігрантів в загальній чисельності населення світу збільшилася з 2,8 відсотка в 2000 році до 3,2 відсотка в 2010 році і до 3,6 відсотка в 2020 році [1]. 
За даними [2] у 2019 більшість міжнародних мігрантів (близько 86,5\%) перебували в працездатному віці (20-64 роки), причому за період 2000-2019 років частка мігрантів молодше 20 років незначно зменшилася (з 16,4\% до 14\%) при збереженні незмінної з 2000 року долі ринку міжнародних мігрантів у віці 65 років і старше (близько 12\%). Майже на 2 відсотки, або на 3,2 мільйона, збільшилася з 2017 року і частка молодих мігрантів (у віці від 15 до 24 років). У 2019 їх налічувалося 16,8 мільйона [3].

За кількістю мігрантів Україна займає восьме місце в світі майже 6 млн наших співгромадян емігрували 3 початку незалежності України. Попереду за кількістю мігрантів Індія, Мексика, Російська Федерація, Китай, Бангладеш, Сирія та Пакистан [4].

Головними причинами можливої міграції українці назвали пропозицію прибуткової роботи (28\%) і збройний конфлікт (27\%). Далі йдуть економічні проблеми в країні (19\%) і сімейні обставини (18\%). Замикають список згадуваних причин можливої еміграції відсутність умов для самореалізації (9\%) і політична нестабільність (7\%). Третина українців (29\%) заявили, що ніякі обставини не змусять назавжди покинути країну.

Статистика свідчить, що за I квартал 2021 року зареєстровано 449,7 тис. безробітних, рівень безробіття склав 10,9\%. I цей показник має тенденцію збільшуватися. Також знижується показник відсотку економічно активного населення в загальній чисельності населення, що викликає занепокоєність (рисунок 1). Населення старіє, помирає та мігрує [4].

Згідно дослідження Міжнародної організації з міграції [5] половина українців до 30 років - потенційні трудові мігранти. Через події 2014 року та економічну кризу кількість мігрантів збільшилася, трудова міграція за кордон помолодшала. Молодь шукає краще можливості, вона більш активна, і багато хто з них володію іноземною мовою, тобто йде процес «омолодження» української трудової міграції. 


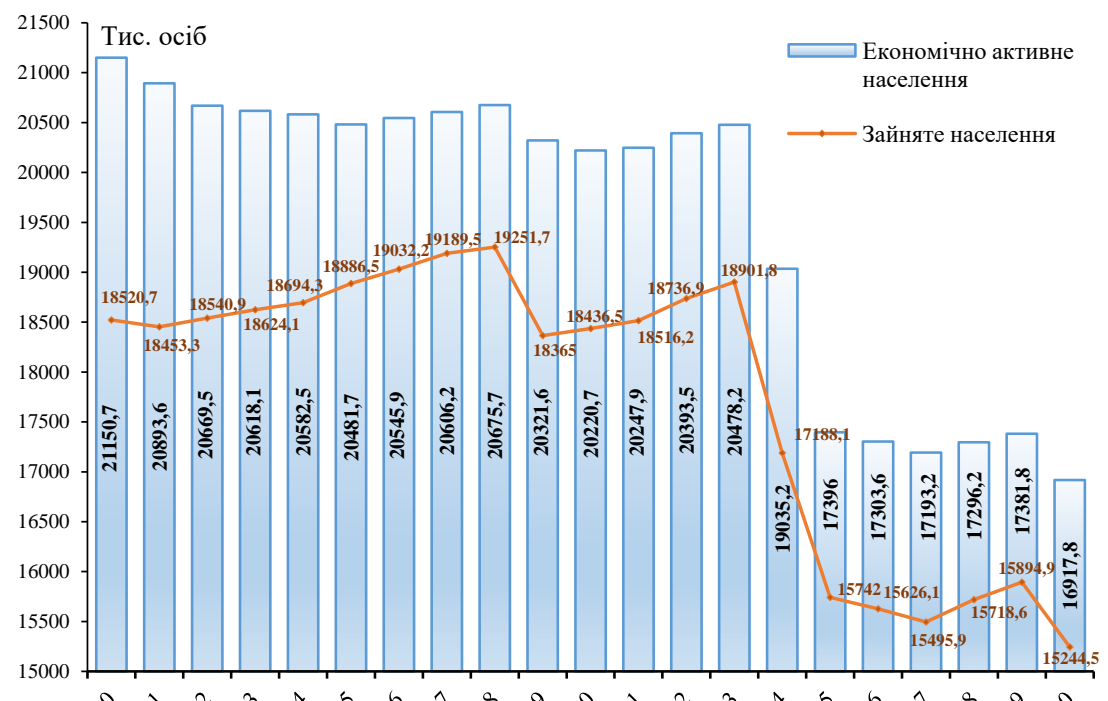

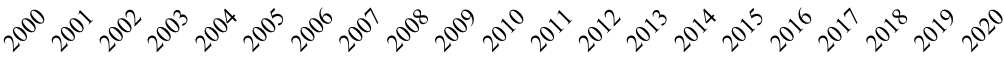

\section{Рис. 1. Динаміка зміни чисельності економічно активного і зайнятого населення України у 2000-2020 рр.}

Примітка: без урахування тимчасово окупованої території Автономної Республіки Крим, м. Севастополя та частини тимчасово окупованих територій у Донецькій та Луганській областях, тис. осіб

Молодь, їде на заробітки за кордон, є найбільш економічно активної, мобільної, висококваліфікованої та освіченої частиною українського суспільства. Отже, трудова міграція «вимиває» 3 України національний середній клас в його традиційному розумінні, тобто тих, хто представляє інтелектуальний потенціал нації і основну складову людського капіталу товариства - тих, від кого залежить іï економічне благополуччя i безпеку в майбутньому. Це означає, що економічний і соціальний кістяк сучасного українського суспільства поступово покидає країну, що є загрозою як для соціальної структури суспільства, для його національної безпеки, так і для індивідуальної людської безпеки людей, залучених в міграційні потоки.

Динаміку змін міграційних процесів України зображено на рисунку 2. 


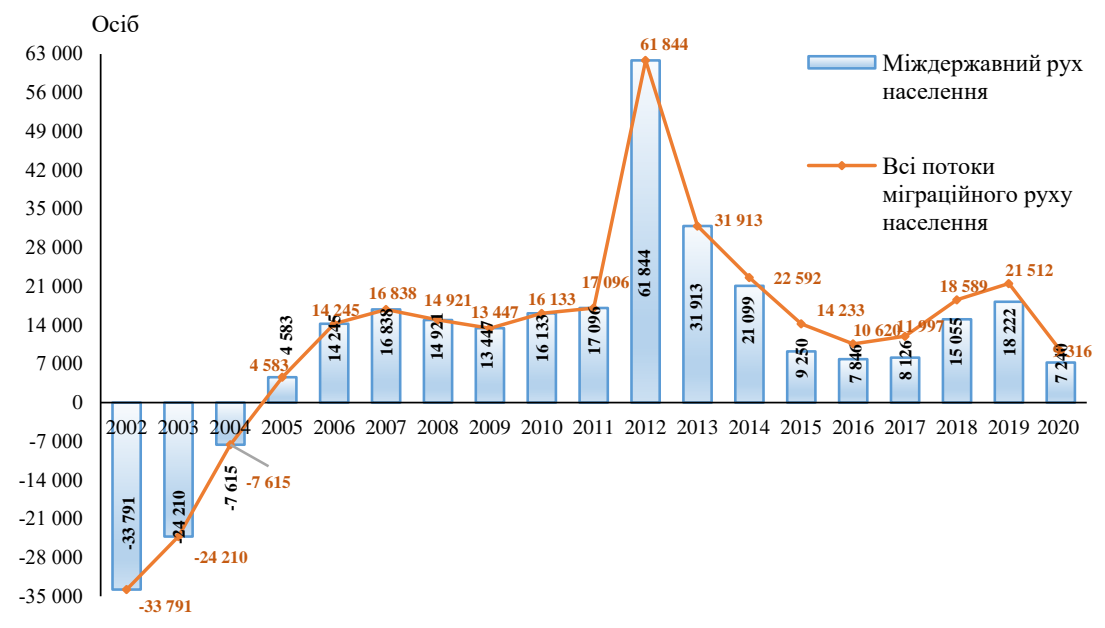

\section{Рис. 2. Міграційний рух населення (приріст, скорочення) України за 2002-2020 рр.}

Примітка: без урахування тимчасово окупованої території Автономної Республіки Крим, м. Севастополя та частини тимчасово окупованих територій у Донецькій та Луганській областях, осіб

Міграційні потоки та управлінські механізми їх регулювання $\epsilon$ важливою передумовою забезпечення стійкості розвитку країни. Результат руху трудових ресурсів значимо впливає на формування інтелектуального, професійного потенціалу, впливає на кон'юнктуру ринку праці та встановлення рівноважної ставки заробітної плати. Істотний вплив, але різної спрямованості і сили впливу, виявляється на країни - учасниці міжнародної міграції: в одних відбувається зниження частки економічно активного населення, в інших, навпаки, нарощування; при цьому істотно може змінюватися якість трудових ресурсів.

Можна говорити про формування так званого «замкнутого кола міграційних тенденцій». Зростаюча в сучасному світі поляризація держав на «розвинені» i «що розвиваються», диференціація країн за рівнем соціально-економічного розвитку та правових гарантій - все це обумовлює акцентування уваги молоді на оцінку можливості професійної реалізації за межами 
країни, в якій здобули освіту. Моніторинг оцінок намірів і дій, що робляться до нарощування можливості трудової міграції, фіксує зростання позитивних рішень щодо переїзду в інші локації, в т.ч. i за кордон. Замкнуте коло міграційних тенденцій ще більше підсилює диференціацію країн: оскільки країни-донори відчувають відтік трудових ресурсів, а країни-реципієнти, навпаки, продовжують стійко нарощувати професійний потенціал.

Тенденції розвитку міжнародної міграції формуються під впливом оцінок суб'єктів щодо рівня соціально-економічного розвитку держав, політики доступності переміщення через кордони i, нарешті, здатності закріплення на території іншої країни.

Таким чином, сучасна модель міжнародної міграції побудована на протиставленні приймають і відправляють держав, коли основні міграційні потоки спрямовані 3 держав 3 більш проблемною соціально-економічною обстановкою в держави 3 сприятливими умовами. При цьому міграція молоді супроводжується особливими наслідками для обох сторін.

\section{Література:}

1. Population Division. URL: https://www.un.org/development/desa/pd.

2. Доклад миграции в мире. URL: https://publications.iom.int/system/files/ pdf/final-wmr_2020-ru.pdf.

3. ILO Global Estimates on International Migrant Workers - Results and Methodology. URL: https://www.ilo.org/global/topics/labour-migration/publications/ WCMS_808935/lang--ru/index.htm.

4. Державна служба статистики України. URL: http://www.ukrstat.gov.ua.

5. The International Organization for Migration. URL: https://www.iom.int. 